\title{
'Let us be given vegetables to eat and water to drink': The diet consumed by Daniel and his friends as clarified in the commentary of Abraham Ibn Ezra
}

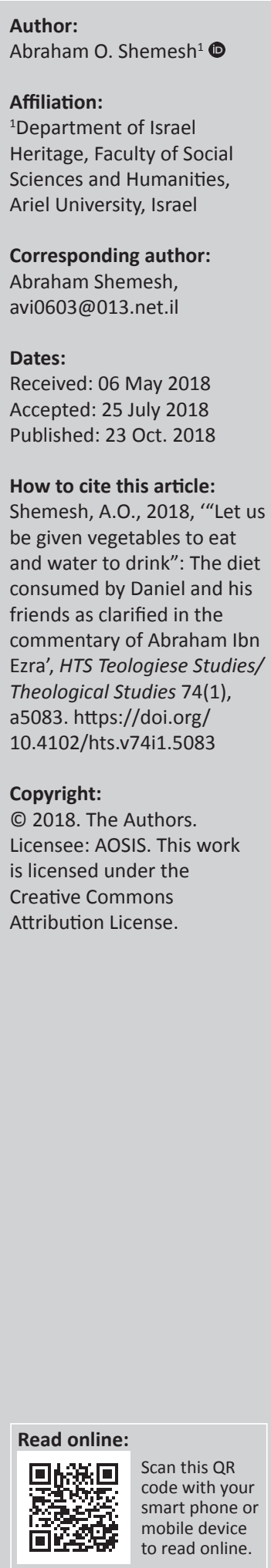

According to the biblical story, Daniel, Hananya, Mishael and Azarya refused to eat the food produced by the Babylonian royal kitchen, asking instead to be provided with vegetables (Dn 1:1-21). The current paper examines Abraham Ibn Ezra's (c. 1090-1164) interpretation of the boys' diet based on contemporary culinary and nutritional habits. Ibn Ezra's basic claim is that Daniel and his friends appeared healthy and well-disposed because they ate rice and chickpea dishes that have a high nutritional value. Ibn Ezra rules out R. Saadya Gaon's approach that it was a supernatural miracle and suggests an interpretation whereby this is a completely natural health outcome. Based on nutritional and medical knowledge, Ibn Ezra claims that the diet consumed by Daniel and his friends was fairly nourishing, and thus it is no surprise that they appeared healthy. Ibn Ezra was strongly influenced by the crops and dishes of Muslim cuisine, as well as by the nutritional-medical outlooks common in the medieval Arab region.

\section{Introduction}

Daniel, Hananya, Mishael and Azarya were skilled boys from King David's lineage and from the Judean aristocracy who were brought to the palace of the Babylonian king to receive an education. The four, who were healthy, good complexioned and educated, were to receive three years of training, at the end of which they would be integrated into the royal hierarchy. The Scriptures relate (Dn 1:5) that they were to have been fed by the royal kitchens, and served choice and refined food. ${ }^{1}$

Royalty, the nobility and the wealthy enjoyed high-quality food, such as meat, and larger quantities than the average population. They were naturally fatter and healthier, and therefore obesity was a status symbol of the high classes and was also considered an indication of health and abundance. Daniel and his friends forwent the nutritional benefits and refused to eat the food produced by the royal kitchens, asking instead to be provided with vegetables (in the text: zeronim, i.e. seeds) (Dn 1:12, 16).

To the surprise of the chief of the eunuchs, who was in charge of their nourishment, his concern that their health would be affected and that their complexion would seem poorly and sad (Dn 1:10) was disproved, and the new diet had the opposite effect: 'they were better in appearance' and they were 'fatter in flesh' (Dn 1:15). The quotations are according to the Revised Standard Version (RSV), that is, their good appearance remained as it was and they were fairly healthy-fat. The effect of a lack of food on one's appearance is described in the Bible in contexts of extreme hunger. The author of the Scroll of Lamentations speaks of the drastic change in the appearance of residents of Jerusalem as a result of the hunger they suffered during its siege and destruction. To begin with, they had light coloured skin, but the hunger they suffered darkened and toughened it (Lm 4:8).

The purpose of the current paper is to examine R. Abraham Ibn Ezra's interpretation of the boys' diet based on contemporary culinary and nutritional habits. As I shall show, Ibn Ezra was strongly influenced by the crops and dishes of Muslim cuisine, as well as by the nutritional-medical outlooks common in the medieval Arab region.

R. Abraham Ibn Ezra (c. 1090-1164) was born in Toledo, in Muslim Spain. He operated in Spain for the first five decades of his life, and during this period he travelled to different countries in 1.On the serving of bread, types of meat originating from various animals and fine wine at royal feasts, see: I Kings $5: 2-3$; Esther $1: 7$. On the provision of food and feasts in palaces with an emphasis on the Mesopotamian region, see Finet 1992:31-43; Grayson 1991:292-293; Postgate \& Fales 1992:31-32. 
North Africa, such as Tunisia, Morocco and Algeria. Following the occupation of Al-Andalus (Muslim Spain or Islamic Iberia) by the Murābițūn (مر ابطون) tribes in 1090, and then the Al-Mohads (al-Muwahhịidn الموحدون) in 1145, many Jews and Christians, among them Ibn Ezra, were compelled to migrate to Christian countries. For the next three decades he travelled to Christian countries in Western Europe - Italy, France and England - where he utilised the knowledge he had amassed in his youth and adulthood to interpret biblical literature. ${ }^{2}$ Ibn Ezra, an intellectual and fertile man of science, engaged in varied fields: Biblical commentary, linguistics, philosophy, liturgical poems, mathematics, astronomy and astrology. ${ }^{3}$

\section{Daniel 1:1-21: Review of interpretations}

Beginning from the post-biblical period, scholars and commentators proposed various explanations of how Daniel and his friends maintained their health while avoiding basic foods such as bread and wine. The major approach in Jewish sources is that this was a supernatural miracle. Midrash Tanhuma presents the outlook whereby Daniel and his friends were given this miracle as a reward for overcoming temptation and not eating the king's dishes (Tanhuma 1883: Parashat va-Year, 29). A similar approach is also evident in the literature of late traditional Jewish commentators, for example, R. Moshe Alsheikh (Turkey and Land of Israel, 16th century) and R. Meir Leibush son of R. Yehiel Michel Wisser (Malbim, Ukraine, 19th century) in their commentaries on the Book of Daniel (Alsheikh 1876, Dn 1:15; Wisser 2017, Dn1:15).

A compromising approach that combines miracles and nature appears in the commentary of R. Tanchum ben Yosef ha-Yerushalmi, a 13th century biblical commentator and lexicographer. He claims that divine supervision indeed had a part in this but there were also natural influences. According to his outlook, eating even a small quantity of food in a state of mental composure and comfort is more nourishing and beneficial for the body than the most nourishing and fat food eaten with a sense of abhorrence and revulsion (Tanhum 1981:24). In other words, Daniel and his friends desired the simplest diet and thus it was better for their health than the food served by the royal kitchens. As we shall see below, Ibn Ezra presents a similar approach, whereby food that is agreeable to those dining is more nourishing than food eaten unwillingly, and this seems to have been a common medicalnutritional outlook in medieval times.

The Book of Daniel mentions four kingdoms (chapters 2, 7), and most of the modern scholars agree that they represent Babylon, the Medes, Persia and that of the Greeks (Koch 2001:422; Segal 1967:729-756). The consensus of the critical scholarship is that the final form of the Book of Daniel was

2.On Ibn Ezra's date of birth and biography, see Kislev 2009:282-297; Levine 1970:9-46; Melamed 1978:II, 519-520; Veizer 1976:7-51.

3.See Goldsstein 1996:9-21; Langermann 1993:28-85; Sela 1999:72-85; Sela and Freudenthal 2006:13-55; Zarfati 1968:130-155. compiled not before the religious persecutions which took place in Judea in 167-164 BC when Antiochus IV Epiphanes (c. 215 BC - 164 BC), the Greek king of the Seleucid Empire, threatened to destroy traditional Jewish worship in Jerusalem (Koch 2001:421-446). Accordingly, the story on Daniel in the Babylonian palace and the visions (chapters 7-12) neither reported a miracle nor a nutritional consequence but served to encourage Jews to refuse to compromise to Hellenistic culture in the time. Hence, the message of the Book of Daniel is that, just as the God of Israel saved Daniel and his friends from their enemies, so he would save Israel from their present oppressors, that is, the Greeks (Segal 1967:729-756). Against that background, it is not necessary to explain whether the diet of the boys had a beneficial effect, although it would have been important for Ibn Ezra and other Jewish commentators who would not have doubted its historicity.

\section{Diet consisting of 'seeds' - Rice and chickpeas}

Based on the nutritional and medical knowledge at his disposal, Ibn Ezra claims in his long commentary on Daniel 1:15 that the diet consumed by Daniel and his friends was fairly nourishing, and thus it is no surprise that they appeared healthy. He says:

The reason for their appearance, the Gaon said: this was a great miracle, but this is not necessary because they were accustomed to eating rice called aroz in the Arabic language and it is very substantial and more agreeable than wheat and it generates pure blood and it is the food of the people of India and they have no wheat and it is used to prepare cooked dishes and this rice is superb when cooked in milk and the rule is that a small amount is filling and its weight is heavy and its kernels are very thin and not round and its outcome is hot and moist. (Dn 1:15, [Author's own translation])

Ibn Izra states that according to R. Saadya Gaon (Rasag, $882 / 892$ - 942), the continued health of Daniel and his friends is to be considered a miracle. Nevertheless, it is notable that the claim attributed to R. Saadya Gaon does not appear in his commentary on Daniel 1:15 as we have it (Rasag 1981:22-23). And this has already been noted by Yosef Kapach who mentioned that this section is missing from the commentary as we know it (Rasag 1981:23-24).

Ibn Ezra objects to the miraculous interpretation and claims that this was a completely rational phenomenon, as they appear to have subsisted on nourishing foods. Further on, Ibn Ezra assumes that the new diet was based on certain species of peas (afunim) and rice known by the Arabic name

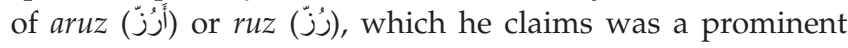
food that is tastier than wheat (Figure 1).

The assumption that the group subsisted on rice-based foods is very problematic, as rice was not familiar in biblical countries. Rice originates from south west Asia (Indochina), and it reached the Near East in the Hellenistic period. ${ }^{4} \mathrm{Ibn}$ Ezra assumes that rice was a well-known product in Babylon 4.See Smartt and Simmonds 1995:147-155; Zohary and Hopf 1994:84-85. 


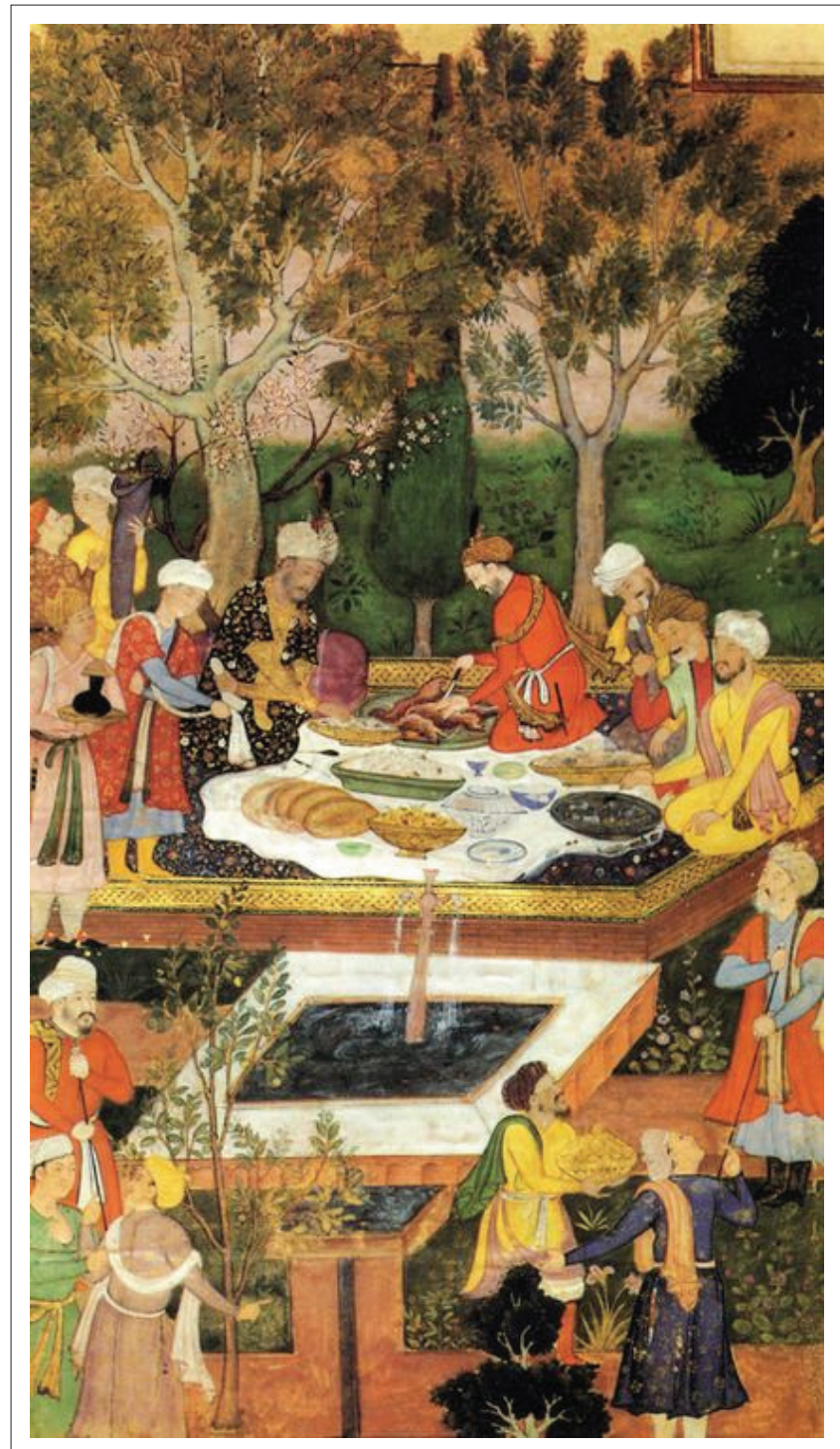

Source: The Museum of Oriental Art Moscow, n.d., Babur Entertained by Badi uz-Zaman Mirza in the Jahan Ara Garden in Herat, viewed n.d., from http://museums.artyx.ru/books/ item/f00/s00/z0000008/st029.shtml

Note: Babur Entertained by Badi uz-Zaman-Mirza in the Jahan Ara Garden in Herat Miniatures from the Babur-Nama manuscript. India. Mogul style. Late 16th century The Museum of Oriental Art, Moscow.

FIGURE 1: Eating roast meat (goose?), rice and bread.

in the time of Daniel and his friends, but it seems that there is no proven historical basis for this. Rice is not mentioned in the Bible but is often mentioned in rabbinical literature. ${ }^{5}$

The Jerusalem Talmud included rice among the seeds, and this may have affected Ibn Ezra's interpretive suggestion that Daniel and his friends subsisted on it (Jerusalem Talmud, Berakhot 6:1, 10b). Moreover, it may be assumed that Ibn Ezra thought that rice was well-known in ancient periods because in the Muslim era in his own time use of rice had expanded and the impression was that it had existed in the area from time immemorial (Canard 1959:113-131; Watson 1983:15-19).

Even if we assume that the royal group subsisted on rice, as proposed by Ibn Ezra, it is notable that according to another 5.See Broshi 1987:19; Felix 1963:177-189; Löw 1924, I: 730-738. medieval nutritional approach, the change in their diet would not necessarily have produced good results. The medieval Sephardic Jewish philosopher and physician Moses Maimonides (1138-1204) claims in his composition, Regimen of Health, that it is not healthy to change one's eating habits and regular nutritional components. He cites, for example, the transition from eating bread made of grains to bread made of rice and vice versa among Indian people and people in Near Eastern countries used to eating different kinds of grain:

If one of the people of India were to eat [for example] bread [made of Wheat] or mutton, he would necessarily sicken; and if one of us [i.e., from the Near East] would regularly eat rice and fish similar to the practice of people in India, he would necessarily sicken. (Maimonides 1957:42, and compare Falaquera 2004:88)

In other words, a transition from eating grain to rice might cause someone who is not used to it to become sick. Hence, Maimonides would not have agreed to Ibn Ezra's approach whereby Daniel and his friends appeared healthy because they ate rice.

\section{Rice - Its nutritional value and its usage in recipes that appear in contemporary literature}

Humoralism, or the doctrine of the four temperaments, was a nutritional-medical theory originating from the Hellenistic world, utilised in Christian Western and Muslim Eastern medicine until the 17th century. According to this doctrine, there are four elements (earth, air, fire and water), four personality types (sanguine, choleric, melancholic and phlegmatic) and four humors (blood, yellow bile, phlegm and black bile) in nature and in the human body. The humors reflect one's temperament and nature and also influence one's physical and mental behaviour. The Roman physician Galen (AD 129 - c. 200) claimed in his dissertation, 'De temperamentis', that there are physiological reasons for different behaviours in humans. He classified them as hot-cold and dry-moist, taken from the four elements and the food that one eats. ${ }^{6}$

As stated, Ibn Ezra claims that rice has positive nutritional and medical qualities. According to the doctrine of temperaments or humors prevalent in medieval times, rice was considered a 'hot' and 'moist' food that purifies the blood. Nonetheless, it is notable that other medieval doctors define rice as hot and dry rather than hot and moist as described by Ibn Ezra (Falaquera 2004:112; Maimonides 1961:255). According to Ibn Ezra, the nutritional quality of rice can be proven based on actual reality. The diet of Indian people centres on rice rather than wheat, which is the basic Mediterranean grain, but they still maintain a regular and healthy life routine. Moreover, some rice dishes are particularly nourishing, such as rice in milk, and therefore it is to be assumed that they ate such dishes.

Medieval Muslim literature has records of various rice recipes, such as cooking rice with grape honey, sugar, meat 6.On this theory and its application in medieval medicine see: Talbot 1978, 391-428. 
or legumes. ${ }^{7}$ Similar to Ibn Ezra, many works report dishes made of rice and milk, and some commend this combination. ${ }^{8}$ A conspicuous example is found in the 10th-century cookbook Kitab al-Tabihh(كتاب الطبيخ, The Book of Dishes) of Ibn Sayyār al-Warrāq (ابن سيار الوراق) of Baghdad, who documented 600 recipes from Muslim cuisine. He devotes an entire chapter (51) to simple cereals made of rice and milk (aruziyat). The recipes include use of raw milk or cultured milk (aruz bileben, أرُزْ بلَبَن) with almond oil, white sugar, spices, honey, etc. (Nasrallah 2007:261-263).

A proper balanced diet had an important role in medieval Arab medicine and was a means of treatment preferred over medications. This diet usually included grains, vegetables, milk products, fruit and meat (Hamarneh 1969, 1974) Contemporary medical works recommend cooking rice in milk, as the nutritional value of this dish is higher, and it does not cause constipation of the stomach. On this matter, R. Nathan ben Yoel Falaquera who lived and operated in Spain in the second half of the 13th century, for example, writes: 'And if it [the rice] is cooked in milk and almond oil it will be more nourishing and will not constipate [=cause constipation]' (Falaquera 2004:112).

Ibn Ezra also refers to the quantities of food necessary to feed Daniel and his friends. He says that they did not have to eat large amounts of seeds, as rice is nourishing and filling even in small quantities. The kernels are indeed thin but their weight is greater than that of wheat. He refers to rice by its Arabic name in order to emphasise that this is Asian rice (Oryza sativa) and not some other product as claimed by some commentators. Indeed, in the second part of his interpretation, he voices strong criticism of a 'great sage' who identified the rice of Talmudic literature (rice is not mentioned in the Bible) with proso millet (Panicum miliaceum), and he writes:

I am surprised at a great sage who said that [rice] is millet whose kernels are round and it can remain for many years without rotting and it is a bad food whose outcome is cold and dry. (Dn 1:15, [Author's own translation]

It appears that the sage whose name Ibn Ezra avoids mentioning is R. Shlomo Yitzchaki (Rashi, 1040-1105), who in his commentary on the Talmud identified rice with 'mil', that is, millet. Notably, Rashi suggested identifying the seeds in Daniel 1:12 in general as a 'type of legume', and Ibn Ezra is clearly referring to his Talmudic commentary on Tractate Berakhot 37a, which identifies rice as 'mil' in old French (Katan 1984:3). In many other cases as well, Ibn Ezra does not mention the names of sages with whom he takes issue in order to avoid disrespect, although he sometimes refers to them vehemently and disparagingly. According to Gross (1993:28-29), Ibn Ezra is the first Spanish sage to mention Rashi's commentary, although he normally tends to disregard the commentators of northern France, that is, Rashi, R. Yosef Kara and the R. Shmuel ben Meir.

7.See Al-Qazwīnī 1849:308; Ibn al-Bayțăr 1875: I, 18-19; Martinelli 2012:52, 54 .

8.See Fabri 1896: Vol. 1, Part 1, 255; Levanoni 2005:210; Pietro 1907:238.
Ibn Ezra claimed that French sages are not proficient in Hebrew grammar and that their unfamiliarity with the Arabic language acts against them in matters of syntax and linguistics. In the case we have before us, he alludes to Rashi's unfamiliarity with the Muslim culture, that is, the role of rice in Arab cuisine, and unfamiliarity with the language, that is, he switched rice with millet owing to the similarity between the word orez and its Arabic parallels. Simon (1985:23-42) showed that Ibn Ezra adhered to the approach whereby the field of grammar belongs exclusively to the Jews of Spain, and therefore he did not see Rashi as a worthy opponent.

Ibn Ezra emphasises the botanical-morphological and medical differences between rice and millet: Unlike rice, whose kernels are elongated, millet kernels are round. In the doctrine of temperaments, millet is considered cold and dry and is therefore a bad food. R. Nathan ben Yoel Falaquera too attributes negative nutritional qualities to millet and its products. He writes:

Millet, dakhan [دخن] in Arabic and milieu [Panicum miliaceum] in foreign languages, is cold and dry and constipates the stomach and dries the body. And the bread made of it is hard to digest and heavy. (Falaquera 2004:120)

As shown by several researchers, in the Middle Ages, rice was still an agricultural and culinary innovation in European countries. In northern and central Europe, where rice was an imported crop and not at all common in extensive areas, it was not well-known. In contrast, in southern Europe where the grains were regularly imported or grown (in small quantities), it was more familiar. In Eastern countries and in the Mediterranean Basin, which were under Muslim influence, rice was a common and primary food in the local diet. To this day, a rich array of choice dishes are prepared from its kernels in Muslim cuisine, together with meat, vegetables or milk products, as stated by Ibn Ezra (see above). Rashi, who lived in northern Europe, mistakenly thought that the rice of rabbinical literature is identical to millet, while Ibn Ezra, who operated in Spain in his first five decades, was familiar with it and with its culinary merits, and was therefore surprised that Rashi identified it with an inferior agricultural crop.

\section{'Peas' (afunim) - Types of chickpeas in Mediterranean countries and their nutritional- medical qualities}

Further on, Ibn Ezra claims that also certain legumes, such as afunim (on their identification see below), may have a particularly high nutritional value. He says:

Also among the types of legumes are afunim and these are not those of France that are cold and bad and bloating. And afunim are usually located in Spain and Egypt and Rome and Florence and there are three species, some white and some red and some black and this species is the most superior and the three species are hot and moist and their waters are a cure for the liver and they redden the face more than wine and one can see that those from France have a mouth and the three species have a mouth and rice and afunim are seeds and they cure the flesh. Moreover, any food that the soul desires is more beneficial than food that 
the soul does not desire even if it is hot and moist as the outcome of life. And these ate something that their soul desired and it was beneficial for them. (Dn 1:15, [Author's own translation])

In all periods, legumes occupied an important role in human nutrition (Brothwell \& Brothwell 1969:105-107). Owing to the protein contained in them, legumes are a vital food for populations that consume little food from animal sources for economic, religious and other reasons, earning them the name of 'poor man's meat'. The nutritional significance of legumes was recognised very early. In biblical times, during sieges and famine, bread was made from grain flour mixed with legume flour (Ezk 4:9). Adding legume flour not only increased the amount of dough, rather, as we know today, but the nutritional value of the bread produced in this way was higher owing to the carbohydrate and protein content (amino acids) that is required by the body in times of need (Felix 1992:217-218).

By the term 'peas' (afunim), Ibn Ezra meant chickpeas (Cicer arietinum) rather than the green peas (Pisum satioum) of modern-day Hebrew, and indeed the colour of the kernels he describes further on supports this. According to Ibn Ezra, sages in northern France not only provided a mistaken identification of rice but also could not understand the contribution of chickpeas to nutrition, as only inferior species grew in their countries. In other words, there was a difference between the agricultural reality in northern France and in the southern countries, and this difference might have affected the understanding of the story concerning the nutrition of Daniel and his friends. In northern France, afunim with low nutritional quality are grown.

According to the doctrine of temperaments, it is necessary to maintain a balance between the phlegms. Foods that are 'hot and moist' are healthier as they match the basic quality of the body's warmth and its fluids, while foods that are 'cold and moist' might generate white bile and cause health disorders. French afunim have a 'cold' nature and are 'bloating' (menaphim, in Arabic nafha (نفخة), that is, they cause the stomach to become bloated with gas. Various medieval physicians have written about the negative effects of bloating for the body (Maimonides 1961:102, 243, and compare Bunafus 1798, 65b: 'Bloating is of the spirits that are formed in the stomach that harm the breath and the body') and some reported several 'bloating seeds', such as fava beans and lentils (Maimonides 1957:80).

Ibn Ezra reports that in Egypt and in southern European countries on the Mediterranean coast, that is, Spain, Italy and Provence (southern France), three choice cultured species of chickpea are grown. The seeds of these three species appear in red, black and white (these types of chickpea, differentiated by colour, are known today as well, see Fahan, Heller \& Avishai 1998:198) and they are distinguished from the northern France species as 'they have a mouth', that is, a type of tip that protrudes from the seeds (the expression 'it has no mouth' is utilised in Talmudic literature with regard to lentils [Lens culinaris] see Theodor \& Albeck 1903:63, 34; Baba Batra 16b).
Aside from Egypt, where there is no proof that Ibn Ezra visited, he stayed in or travelled through various countries in northern Africa, including Tunisia, Morocco and Algeria. Thus, Ibn Ezra utilised the agricultural knowledge he gathered in the Islamic-Arabic world to understand the gastronomical aspects of the story of Daniel and his friends, while expressing reservations at the interpretations proposed by rabbinical authorities who lived in countries that, in his opinion, did not reflect the culinary world of biblical countries.

Ibn Ezra states that according to the doctrine of temperaments, the species that grow in the Mediterranean area are considered hot and moist, and their fluids are most beneficial for the liver and even generate a better complexion ('redden the face') than wine, which Daniel avoided drinking (Dn 1:8). 'Reddening the face', that is, a healthy and happy complexion, was associated over the generations with eating various food products, such as garlic and olive oil. ${ }^{9}$ The positive effect of chickpeas on the liver and on one's complexion was mentioned by Falaquera (2004):

and the black [=dark colored chickpea] will open blockages in the liver and spleen. And Ibn Sīnā (Avicenna, 980-1037, the Persian polymath and physician) wrote [...] and [the dark colored chickpea] will improve the complexion and clean the marks [=blotches and skin lesions]. (p. 112)

Moreover, aside from their choice nutritional qualities, afunim and rice are also agreeable to those who eat them. Tasty food is eaten willingly, and its health impact is greater than that of food eaten unwillingly and with no desire even if it is healthier (hot and moist). The nutritional outlook whereby food eaten willingly is more beneficial for the body than healthier food appears in other medieval medical works as well. For instance, R. Nathan ben Yoel Falaquera (2004) said:

When there are two foods of which one is good but the person's nature does not desire it [=the body's temperament, bowel movements, or 'force leading the body'] and the second is less good than the first but the person desires it, he should eat that which he desires even if it is not good because it will be more beneficial for the body. (p. 88)

This outlook may have been based on the presumption that appetite indicates a bodily need just as when a person is hungry.

\section{Rice and chickpea dishes to cure gauntness}

According to Ibn Ezra, rice and chickpeas were very healthy nutritional elements for Daniel and his friends and they contributed to a good complexion and to their being 'fatter in flesh'. An anonymous 13th century cookbook mentions a recipe for a dish called Jashîsha (جاثشيشة), which comprises these two ingredients, and it was recommended for fattening thin men and women:

Good Jashîsha: It Fattens Thin Women and Men [wheat, rice, chickpea mush]

9.See Psalms 104:15; Baba Kama 82a; Greenup 1909, Song of Songs, 31. 


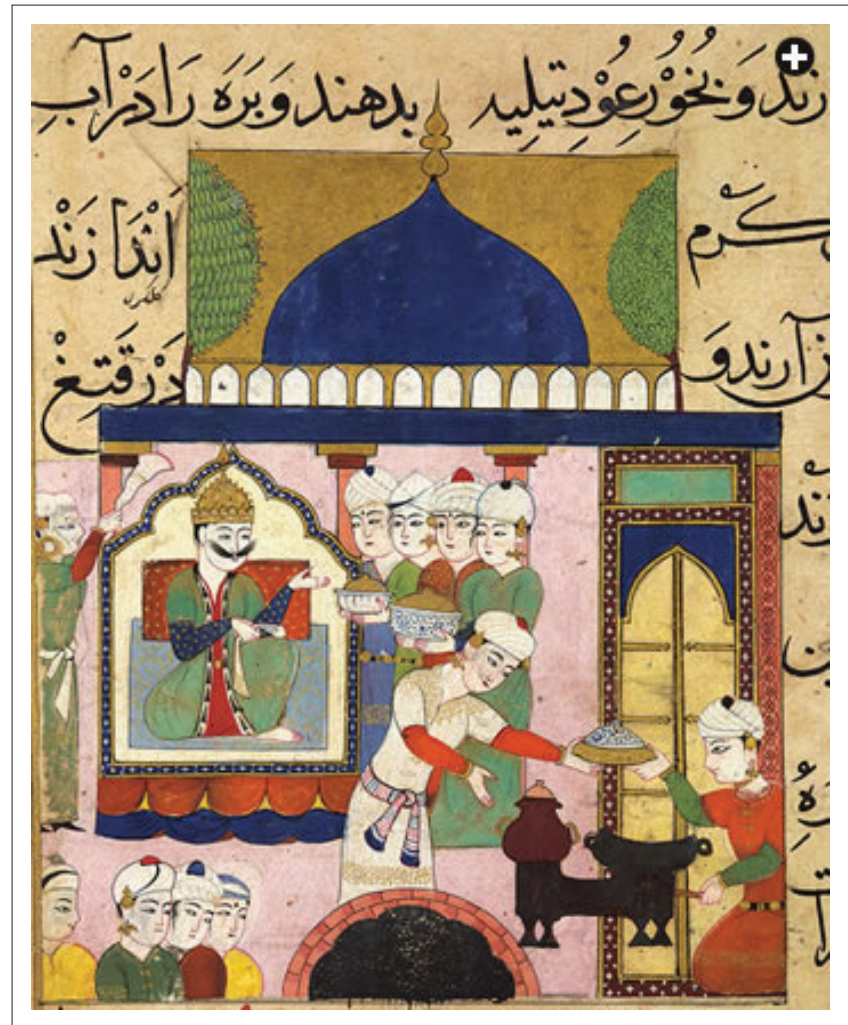

Source: Aramco World, 2014, Book of Delights, viewed n.d., from http://archive aramcoworld.com/issue/201406/crossroads.and.diasporas.a.thousand.years.of.islamic. cuisines.htm

Note: An illustrated chronicle of recipes. The late 1400s, from Mandu, India. The Sultan Ghiyath al-Din receiving dishes prepared by his royal kitchen.

FIGURE 2: The Book of Delights

Take crushed wheat and an equal amount of rice, and garbanzos and hulled and washed spices, a handful of each, and put it in a pot. Cover it with water and cook until it is completely done. Adjust it with a little salt. And so that it is delicate like hasa' [soup], pour on fresh butter and melted kidney fat and the broth of young, fat meat. Then sip it, because it increases one's strength greatly (Martinelli 2012:54).

The recipe includes nourishing components such as protein, carbohydrates and fats. It is to be assumed that it was initially intended for people who suffer from problems of gauntness or extreme weight loss (for instance, in cases of intestinal inflammations such as colitis), but it might certainly have been beneficial for people whose diet was restricted (Figure 2).

\section{Summary and conclusion}

Ibn Ezra's basic claim is that Daniel and his friends appeared healthy and well-disposed although they did not subsist on the choice food offered by the royal kitchens because they ate rice and chickpea dishes that have a high nutritional value. Ibn Ezra, as stated, rules out the miraculous approach and suggests an interpretation whereby this is a completely natural health outcome. Ibn Ezra's interpretation is based on three knowledge domains he acquired during his studies and travels:

1. His knowledge of Arab cuisine that offers many tasty and nourishing rice dishes beside dishes made of different varieties of legumes.
2. Familiarity with the agricultural world and the differences between crops in northern France versus the southern parts of the European mainland and the Mediterranean Basin. Based on these differences, he explains that the legumes eaten by the group in question are nutritionally similar to the nourishing and healthy legumes of Spain and Egypt.

3. Knowledge of nutrition, that is, mentioning the positive qualities of rice and varied legumes according to the doctrine of humors prevalent in his time. The discussion of the food eaten by Daniel and his friends is based on the guiding principle in contemporary medical literature, whereby a proper and balanced diet may solve medical problems and ensure good health.

With regard to rice, it appears that the attempt to observe circumstances in the Muslim region as reflecting life routines in biblical countries was not helpful. The assumption that Daniel and his friends ate rice is disproved as rice was only introduced to the Near East in the Hellenistic period and its attribution to the biblical period is an anachronism.

Aside from elaborating on the nutritional qualities of rice and legumes, in his biblical commentary Ibn Ezra also addressed the qualities of other foods. For example, the nutritional significance of cooking meat with milk, forbidden in the Bible (Long and Short Commentary: Ex 23:19), and of eating bitter herbs (maror) on Passover keeping with the biblical commandment: 'They shall eat the flesh that night, roasted; with unleavened bread and bitter herbs they shall eat it' (Ex 12:8).

In his long commentary on Exodus 12:8, Ibn Ezra discusses the approach whereby eating bitter herbs with the Passover offering on the night of the exodus from Egypt stems from a medical need associated with Egypt's humid air. He writes:

One of the Spanish sages said that there is a greater amount of phlegm in the Land of Egypt due to the water of the Ye'or [Nile], and since it does not rain there the air is always humid so they are accustomed to having on their table many types of bitter herbs consisting of herbs and mustard. And even if an Egyptian had only bread, the bitter herbs would always be on his table to dip his bread in, as they are a cure for their air. And we shall rely on the view of our ancients, who interpreted for us that the bitter herbs were in memory of 'they made life bitter for them'. (Ex 1:14, [Author's own translation])

The concern of the large amounts of phlegm generated by the water of the Ye'or is interpreted as an excess of white bile, associated with the element of water and the cold and humid temperament. Ibn Ezra does not reject the explanation suggested by the Spanish sage but rather prefers the ancient symbolic interpretation of the Sages whereby the bitter herbs symbolise the bitter life and hard work of the Israelites in Egypt. Nonetheless, it is to be assumed that he chose not to disregard this interpretation as he believed that the nutritional theory is legitimate for explaining the laws of the Torah. 
Ibn Ezra is not known as a physician, although some attribute to him the writing of medical works (Leibowitz 1966). As we have seen, his nutritional explanations are based on the doctrine of temperaments or humors that formed the foundation of medieval diagnosis and treatment, and the views he voices have parallels among other physicians of his era, proof of his updated knowledge in the nutritionalmedical field.

\section{Acknowledgements Competing interests}

The author declares that he has no financial or personal relationships that may have inappropriately influenced him in writing this article.

\section{References}

Al-Qazwīnī, Z.I.M., 1849, Ajaib al-makhlūqāt wa gharāib al-mawjūdāt [Wonders of the creation and unique (phenomena) of the existence], Dieterich, Göttingen.

Alsheikh, M., 1876, Havatzlet ha-Sharon: Commentary on Book of Daniel, Goldman, Warsaw.

Aramco World, 2014, Book of Delights, viewed n.d., from http://archive.aramcoworld. $\mathrm{com} /$ issue/201406/crossroads.and.diasporas.a.thousand.years.of.islamic. com/issue/201
cuisines.htm

Broshi, M., 1987, 'Regarding the foods of the people of Eretz Israel in the Roman period', Cathedra 43, 15-32. (Heb.)

Brothwell, D. \& Brothwell, P., 1969, Food in antiquity: A survey of the diet of early peoples, Thames and Hudson, London.

Bunafus, M.A.-P., 1798, Sefer ha-Gdarim, Y. Stanev edn., Berlin. (Heb.)

Canard, M., 1959, 'Le riz dans le Proche Orient aux premiers siecles de I'Islam', Arahica 6(2), 113-131.

Fabri, F., 1896, Palestine Pilgrims' Text Society (PPTS), Felix Fabri (circa 1480-1483 A.D.), London Committee of the Palestine Exploration Fund, London.

Fahan, A., Heller, D. \& Avishai, M., 1998, The cultivated plants of Israel, Kibbutz Hameuhad, Jerusalem. (Heb.)

Falaquera, N.B.Y., 2004, Sori Haguf by R. Nathan ben Yoel Falaquera, Z. Amar \& Y. Buchman edn., Oren Hafakotot Dfus, Tel Aviv. (Heb.)

Felix, Y., 1963, 'The Rice in Sages Literature', Bar Ilan 1, 177-189. (Heb.)

Felix, Y., 1992, Nature and land in the Bible: Chapters in Biblical ecology, Reuven Mass, Jerusalem. (Heb.)

Finet, A., 1992, 'Le Banquet de Kalah offert par le roi d’Assyrie Ašurnasirpal II (883859 )', in R. Gyselen (ed.), Banquets d'Orient, pp. 31-43, Groupe pour l'Étude de la Civilisation du Moyen-Orient, Paris.

Goldsstein, B.R., 1996, 'Astronomy and astrology in the works of Abraham ibn Ezra', Arabic Sciences and Philosophy 6, 9-21. https://doi.org/10.1017/S0957423 900002101

Grayson, A.K., 1991, Assyrian rulers of the early first Millennium BC I (1114-859 BC), (Royal Inscriptions of Mesopotamia Assyrian Period, 2), University of Toronto Press, Toronto.

Greenup, A., 1909, Pesikta Zutrata (Lekach Tov) on Song of Song, st. John's Hall, London.

Gross, A., 1993, 'Spanish Jewry and Rashi's Commentary on the Pentateuch', in Z.A. Steinfeld (ed.), Rashi Studies, pp. 27-56, Bar Ilan University Press, Ramat Gan. (Heb.)

Hamarneh, S., 1969, 'Origin of Arabic drug and diet therapy', Physis 11, 267-286.

Hamarneh, S., 1974, 'Ecology and therapeutics in medieval Arabic medicine', Sudhoffs Arch 58(2), 165-185.

Ibn al-Bayțār, 1875, Kitāb al-Jāmi' li-Mufradāt al-Adwiya wa-l-Aghdhiya, Būlāq, Cairo.

Katan, M., 1984, Treasury of Rashi's foreign words: The French words in Rashi's interpretations of the Talmud, Gitler, Tel Aviv, Jerusalem. (Heb.)
Kislev, I., 2009, 'The relationship between the Pentateuch commentaries composed by R. Abraham Ibn Ezra in France and the significance of this relationship for the biographical chronology of the commentator', Journal of Jewish Studies 60 282-297. (Heb.) https://doi.org/10.18647/2883/JJS-2009

Koch, K., 2001, 'Stages in the canonizations of the book of Daniel', in J.J. Collins, P.W. Flint \& C. VanEpps (eds.), The Book of Daniel: Composition and reception, vol. 2 pp. 421-446, Brill, Leiden.

Langermann, Y.T., 1993, 'Some astrological themes in the thought of Abraham ibn Ezra', in I. Twersky \& J.M. Harris (eds.), Rabbi Abraham ibn Ezra: Studies in the writings of a twelfth-century Jewish Polymath, pp. 28-85, Harvard University Press, Cambridge.

Leibowitz, J., 1966, 'Eyes diseases in "Sefer ha-Nisyonot" with attributed to Abraham Ibn Ezra', ha-Refuah 70, 248-249. (Heb.)

Levanoni, A., 2005, 'Food and cooking during the Mamluk Era: Social and political implications', Mamluk Studies Review 9(2), 222-201.

Levine, I., 1970, Abraham Ibn Ezra: His life and his poetry, HaKibbutz HaMehuchad, Tel Aviv. (Heb.)

Löw, I., 1924-1934, Die Flora der Juden, I-IV, R. Löwit, Vienna-Leipzig.

Maimonides, M.B.M., 1957, Hanhagat Habriut [The regimen of healthcare], S. Montner edn., Mosad Harav Kook, Jerusalem. (Heb.)

Maimonides, M.B.M., 1961, Medical aphorisms of Moses Maimonides, S. Montner edn., Mosad Harav Kook, Jerusalem.

Martinelli, C., (trans.), 2012, Anonymous Andalusian Cookbook: Kitab al tabikh fi-IMaghrib wa-l-Andalus fi 'asr al-Muwahhidin, li-mu'allif majhul, The Book of Cooking in Maghreb and Andalus in the era of Almohads, viewed 10 June 2018, from http://italophiles.com/andalusian_cookbook.pdf

Melamed, E.Z., 1978, Biblical commentaries: Their methods and approaches, Magnes Press, Hebrew University, Jerusalem. (Heb.)

Nasrallah, N., (trans. \& introduction), 2007, Annals of the Caliphs' Kitchens: Ibn Sayyār al-Warrāq's Tenth-Century Baghdadi Cookbook, Brill, Leiden.

Pietro, C., 1907, Casola's pilgrimage to Jerusalem in the year 1494, University Press, Manchester.

Postgate, J.N. \& Fales, F.M., 1992, Imperial administrative records, Part I: Palace and temple administration (State Archives of Assyria VII), Helsinki University Press, Helsinki.

Rasag, S., 1981, Daniel with translation and commentary of Rabbenu Sa'adiah ben Joseph [Al-]Fayyumi and commentary of Rabbi Tanhum ha-Yerushalmi, Joseph Kapach edn., Dror, Jerusalem. (Heb.)

Segal. M. Z., 1967, Introduction to the Bible, Kiryat Sefer, Jerusalem. (Heb.)

Sela, S., 1999, Astrology and Biblical Exegesis in the thought of Abraham Ibn Ezra, Bar-Ilan University, Ramat Gan. (Heb.)

Sela, S. \& Freudenthal, G., 2006, 'Abraham Ibn Ezra's scholarly writings: A chronological listing', Aleph 6, 13-55. https://doi.org/10.1353/ale.2006.0006

Simon, U., 1985, 'R. Abraham Ibn Ezra - Between the commentator and his readers', Proceedings of the 9th World Congress of Jewish Studies, the International Congress (Bible and Ancient East), pp. 23-42, World Union of Jewish Studies and Hebrew University, Jerusalem. (Heb.)

Smartt, J. \& Simmonds, N.W., 1995, Evolution of Crops Plants, Longman, London.

Talbot, C.H., 1978, 'Medicine', in D.C. Lindberg (ed.), Science in the middle ages, pp. 391-428, University of Chicago Press, Chicago, IL.

Tanhum Y., 1981, Daniel with translation and commentary of Rabbenu Sa'adiah ben Joseph [Al-]Fayyumi and commentary of Rabbi Tanhum ha-Yerushalmi, Joseph Kapach edn., Dror, Jerusalem. (Heb.)

Tanhuma, M., 1883, Midrash Tanhuma, Levine-Epstin, Vilna.

The Museum of Oriental Art Moscow, n.d., Babur Entertained by Badi uz-Zaman-Mirza in the Jahan Ara Garden in Herat, viewed n.d., from http://museums.artyx.ru/ books/item/f00/s00/z0000008/st029.shtml

Theodor, J. \& Albeck, H., 1903, Genesis Rabbah, Itzkowski, Berlin.

Veizer, A., 1976, Abraham Ibn Ezra Commentary on the Torah, Mosad Harav Kook, Jerusalem. (Heb.)

Watson, A.M., 1983, Agricultural innovation in the early Islamic world: The diffusion of crops and farming techniques, 700-1100, Cambridge University Press, Cambridge.

Wisser, M. L., 2017, Ketuvim: Mikraot Gedolot, Artsekrol-Mesora, Brooklyn.

Zarfati, G. B. A., 1968, Mathematical terminology in Hebrew medieval scientific literature, Magnes Press, Hebrew University, Jerusalem. (Heb.)

Zohary, D. \& Hopf, M., 1994, Domestication of plants in the old world: The origin and spread of cultivated plants in West Asia, Europe and the Nile Valley, Clarendon Press, Oxford. 